\title{
The Role of Hyperbaric Oxygen Therapy in the Treatment of Head and Neck Cancer Patients after Radiotherapy with Dental Implants
}

\author{
Esra Nur Avukat ${ }^{1 *}$ and Canan Akay ${ }^{2}$ \\ ${ }^{1}$ Research Assistant, Eskisehir Osmangazi University, Faculty of Dentistry, Department of Prosthodontics, Turkey \\ ${ }^{2}$ Associate Professor, Eskisehir Osmangazi University, Faculty of Dentistry, Department of Prosthodontics, Turkey
}

*Corresponding author: Esra Nur Avukat, Research Assistant, Eskisehir Osmangazi University, Faculty of Dentistry, Department of Prosthodontics, Eskisehir, Turkey.
Received Date: July 01, 2020

Published Date: July 14, 2020

\begin{abstract}
The aim of this review is to evaluate the effect of hyperbaric oxygen therapy (HBOT) on implant survival in patients who underwent prosthetic rehabilitation with dental implants after radiotherapy and suffered from head and neck cancer (HNC). The search terms used in PubMed and Google Scholar scans were "dental implant", "head and neck cancer", "hyperbaric oxygen therapy" and "radiotherapy". The title and summary are screened for the selection of dental implant studies in patients who have had HNC. Clinical human studies, on irradiated dental implant patients, including randomized controlled trials, prospective controlled trials, and retrospective studies were included in the study. In the literature searches, 29 articles were found and 7 articles that meet the inclusion criteria were included. Prosthetic dental implants have gained importance in the treatment of patients with HNC. In cases where conventional prosthetic treatments are insufficient, dental implants increase retention and stability of dentures. In this way, dental implants enable more effective treatments that increase the quality of life. Currently, there is no consensus on the effect of HBOT on osseointegration and implant survival in cancer patients who receive radiotherapy. When the current limited number of studies are evaluated, it can be seen that HBOT may not provide significant clinical benefit in HNC patients treated with radiotherapy. However, it should be taken into consideration that there are not enough studies on this subject in the literature. Therefore, there is a need for randomized, controlled, double-blind trials with homogeneous patient distribution, longer follow-up, supporting HBOT use after RT.
\end{abstract}

Keywords: Dental implant; Head and neck cancer; Hyperbaric oxygen therapy; Radiotherapy

Abbreviations: ATA: Atmosphere absolute; HNC: Head and neck cancer; HBOT: Hyperbaric oxygen therapy; NM: Not mentioned; ORN: Osteoradionecrosis

\section{Introduction}

The National Cancer Institute defines HNC as a neoplasm that arises in the oral cavity, paranasal sinuses, salivary glands, pharynx and larynx [1,2]. Treatment of HNC is a difficult and long-lasting disease. HNC treatment includes therapies like surgical resection, radiotherapy, chemotherapy or a combination of these [3,4]. 80\% of HNC patients receive radiotherapy at some stage of their treatment [5]. However, high-dose radiation therapy induces many side effects, such as xerostomia, fibrosis of the oral mucosa, mucositis, loss of taste, temporomandibular joint disorders, reduced mouth opening, compromised aesthetics, candidiasis, implant failures and ORN. These complications negatively affect the quality of life of patients $[3,6-10]$.

Successful prosthetic restoration after cancer surgery becomes difficult due to the size, shape and location of the defect. In addition, 
the changes that occur after radiotherapy make the construction of the prosthesis even more difficult. Therefore, careful treatment planning should be done. A good prosthetic rehabilitation is an important factor for patients to regain their lost functions. The changing anatomy makes it difficult or sometimes impossible to treat with removable dentures, especially for patients with completely edentulous. Tissue-supported prostheses are likely to develop trauma $[7,10,11]$. Ulcerations may occur due to dry mouth and sensitive mucosa in patients using removable dentures after radiation. This can cause serious infections or even ORN development [12]. ORN occurs in bones such as the sternum, skull or pelvis, but often affects the mandible. Treatment of ORN is difficult [13].

Intraoral anatomical changes that occur after surgery and radiotherapy make it difficult to prepare a prosthesis with good stability and retention [14]. Dental implants increase the support and stability of dentures. Recently they play an important role in the rehabilitation of cancer patients [7]. With the osseointegrated implants, the retention of the prosthesis is increased and the risks that cause mucous irritation are eliminated. Thus, it is thought that the burden on sensitive soft tissues will be reduced and the possibility of necrosis will be prevented. Patients can better mastication, thus improving their quality of life [15-17].

Many factors are important for implant survivors such as age, gender, applied radiation dose, type of radiotherapy applied, the time between radiotherapy and implant surgery, the quality and topography of the bone in the region where the implant is placed, and the surgical procedure applied. Implants are placed as primary or secondary [18-21]. Placing the implants in the same session as ablative and reconstructive surgery is called primary placement. The primary placement has advantages such as avoiding additional surgery, not needing additional treatments such as HBOT, save costs on extra operating sessions, and osseointegration occurring before radiotherapy $[22,23]$. In secondary implant placement, implants are placed after radiotherapy. Secondary placement provides an advantage to assess the patient's motivation, psychological state, and prognosis of cancer [22]. However, when implants are inserted into the irradiated bone, the rate of failure increases: the side effects of radiotherapy can result in progressive fibrosis of the vessels and soft tissue, resulting in decreased recovery capacity. In addition, radiation decreases bone vascularity, clinically this condition occurs as ORN. This prevents osseointegration of implants. Ionizing radiation damages bone, periosteum, connective tissue and vascular endothelium and causes loss of resistance in tissues. This situation causes hypoxia, hypovascularity, and reducing cell Table 1: A summary of the current literature.

\begin{tabular}{|c|c|c|c|c|c|}
\hline Study & Methods & $\begin{array}{l}\text { Number of patients/ } \\
\text { implants inserted }\end{array}$ & $\begin{array}{c}\text { Radiotherapy dose applied/ No of patients who } \\
\text { received HBOT/ No of HBOT dives }\end{array}$ & $\begin{array}{l}\text { Follow up } \\
\text { duration }\end{array}$ & Conclusions \\
\hline $\begin{array}{l}\text { Shaw RJ, et } \\
\text { al. [22] }\end{array}$ & $\begin{array}{l}\text { Retrospec- } \\
\text { tive cohort } \\
\text { study }\end{array}$ & $77 / 364$ & $\begin{array}{c}\text { 40-66 Gy/ } 16 \text { patients/ Pre-surgery-20/ Post-sur- } \\
\text { gery-10 } 2.4 \text { atm } 90 \text { minutes }\end{array}$ & $\begin{array}{l}\text { Mean } 3.5 \text { years } \\
(0.3-14)\end{array}$ & $\begin{array}{l}\text { There was no significant effect } \\
\text { on implant survival using HBOT. }\end{array}$ \\
\hline $\begin{array}{l}\text { PJ Schoen, et } \\
\text { al. [14] }\end{array}$ & $\begin{array}{l}\text { Prospective } \\
\text { comparative } \\
\text { study }\end{array}$ & $26 / 103$ & $\begin{array}{c}\text { Mean } 61 \text { Gy/ } 13 \text { patients/ Pre-surgery-20 Post-sur- } \\
\text { gery-10 } 2.5 \text { atmospheres } 80 \text { minutes }\end{array}$ & $\begin{array}{l}1 \text { year after } \\
\text { placement of } \\
\text { prostheses }\end{array}$ & $\begin{array}{l}\text { There was no positive effect of } \\
\text { HBOT in terms of implant survi- } \\
\text { val and ORN prevention. }\end{array}$ \\
\hline
\end{tabular}

numbers in the future. However, resistance to trauma and infection decreases [24,25]. Tissue dehiscence and ORN are possible side effects and can cause implant failure [26]. For these reasons, dental implant treatment was accepted as a contraindication in patients undergoing radiotherapy [13]. Long-term use of antibiotics or HBOT has been recommended to prevent the occurrence of these complications [10].

The HBOT protocol was introduced by Marx in 1985. HBOT is a systemic treatment method in which patients inhaled to intermittent, short term $100 \%$ pure oxygen under a pressure of greater than 1 atmosphere in a specially designed chamber, once or twice a week. HBOT protocol is applied as twenty treatment sessions before surgery and ten treatment sessions after surgery. As a result of treatment, the amount of dissolved oxygen in plasma and tissues increases [12, 27-30].

The Hyperbaric Oxygen Committee of the Undersea and Hyperbaric Medical Society currently recommends HBO for several uses, including air or gas embolism, carbon monoxide poisoning, severe anemia, intracranial abscess, necrotizing soft tissue $[13,30]$. It is recommended to use HBOT in risky areas to increase blood flow before implant surgery [31]. It has been reported in published studies that HBOT increases fibroblastic, osteoblastic, and angioblastic activity in tissues [32,33]. The results obtained from the studies, increased bone mineralization and increased force required to remove the implants support these assumptions [14, 31]. However, it should be remembered that HBOT has side effects such as middle ear barotrauma, development reversible myopia, and aggravation of congestive heart failure [13]. In addition, patient compliance must be good for HBOT. However, expensive equipment is required and is a costly treatment for patients [30].

Surgical treatment after radiotherapy can lead to the development of ORN. HBOT has been proposed to improve the success of implant therapy. It has been suggested that HBOT will improve the healing of bone and soft tissues around the implant in patients undergoing radiotherapy. Nevertheless, this issue is still controversial today [12]. Currently, there is no consensus on the effect of HBOT on osseointegration and implant survival development in cancer patients who receive radiotherapy [34]. For this reason, the purpose of the review is to review the use and benefits of HBOT in patients undergoing radiotherapy for HNC. Therefore, the main question asked in the review: What is the role of HBOT in dental implant treatments in HNC patients treated with radiotherapy? infections, refractory osteomyelitis and others (www.uhms.org) 


\begin{tabular}{|c|c|c|c|c|c|}
\hline $\begin{array}{l}\text { Salinas TJ, et } \\
\text { al.[35] }\end{array}$ & $\begin{array}{l}\text { Retrospecti- } \\
\text { ve study }\end{array}$ & $44 / 206$ & $\begin{array}{c}>60 \mathrm{~Gy} / 22 \text { patients/ Pre-surgery-20 Post-sur- } \\
\text { gery-10 } 2.4 \text { atmospheres absolute pressure } 90 \\
\text { minutes }\end{array}$ & $\begin{array}{l}41 \text { months } \\
(4-108)\end{array}$ & $\begin{array}{l}\text { Since HBOT was applied to all } \\
\text { patients who received radiot- } \\
\text { herapy, the difference could not } \\
\text { be evaluated. In addition, it was } \\
\text { found that implant failures were } \\
\text { somewhat high in the group who } \\
\text { received radiotherapy, although } \\
\text { it was not significant. }\end{array}$ \\
\hline $\begin{array}{l}\text { RA Barrow- } \\
\text { man [7] }\end{array}$ & $\begin{array}{l}\text { Retrospecti- } \\
\text { ve study }\end{array}$ & $30 / 115$ & $\begin{array}{l}\text { NM/ } 12 \text { patients/ Pre-surgery-20 Post-surgery-10 } \\
\text { 2-2.5 ATA } 60 \text { minute }\end{array}$ & Up to 15 years & $\begin{array}{l}\text { It has been reported that the } \\
\text { high retention rates achieved } \\
\text { may result from HBOT. }\end{array}$ \\
\hline $\begin{array}{l}\text { Wu Y, et al. } \\
\quad[54]\end{array}$ & $\begin{array}{l}\text { Retrospecti- } \\
\text { ve study }\end{array}$ & $36 / 198$ & 60 minute Less than $50 \mathrm{~Gy} / 14$ patients/ NM & 3 - to 10-year & $\begin{array}{c}\text { There was no significant dif- } \\
\text { ference in implant success in } \\
\text { patients who received HBOT and } \\
\text { not received HBOT. }\end{array}$ \\
\hline $\begin{array}{l}\text { Cotic J, et } \\
\text { al.[9] }\end{array}$ & $\begin{array}{l}\text { Retrospecti- } \\
\text { ve study }\end{array}$ & $20 / 100$ & $\begin{array}{l}\text { 54-66 Gy/ } 16 \text { patients/ Pre-surgery-20 Post-sur- } \\
\text { gery-10 2.5 ATA (1.5 bar) } 90 \text { minute }\end{array}$ & $\begin{array}{l}61.9 \text { months } \\
(1.4-90.2)\end{array}$ & $\begin{array}{l}\text { HBOT had no statistically signifi- } \\
\text { cant effect on implant success in } \\
\text { radiotherapy treatment. }\end{array}$ \\
\hline $\begin{array}{l}\text { Curi M,et al. } \\
\quad[21]\end{array}$ & $\begin{array}{l}\text { Retrospecti- } \\
\text { ve study }\end{array}$ & $35 / 169$ & $\begin{array}{l}62 \text { Gy/ } 13 \text { patients/ Pre-surgery-20 Post-sur- } \\
\text { gery-10 } 2.4 \text { atmospheres absolute } 2 \text { hours per } \\
\text { session }\end{array}$ & $\begin{array}{l}7.43 \text { year }(0.3- \\
14.7)\end{array}$ & $\begin{array}{c}\text { After } 5 \text { years, the implant } \\
\text { success rate was } 88.2 \% \text { in the } \\
\text { HBOT group and } 94.1 \% \text { in the } \\
\text { non-HBOT group. No significant } \\
\text { difference was reported between } \\
\text { the two groups. }\end{array}$ \\
\hline
\end{tabular}

Study, methods, number of patients/implants inserted, radiotherapy dose applied/ no of patients who received HBOT/ no.of HBOT dives, follow up duration, and study conclusion are summarized in (Table 1) articles were reviewed; these are summarized in (Table 1).

\section{Discussion}

Before 1986, patients who had irradiated their head and neck region were not treated with dental implants due to the negative effects of radiotherapy on osseointegration and wound healing [36]. Today dental implant treatment is a reliable treatment method in irradiated HNC patients after surgical and prosthetic procedures are applied correctly [9]. However, oral rehabilitation of cancer patients exposed to radiation should be performed in experienced clinics and a multidisciplinary team, taking into account the complications that may occur $[7,17]$. The team should include medical and radiation oncologists, surgeons, maxillofacial prostodontists, medical engineers, and hyperbaric medicine $[7,22,37]$.

Studies have reported that implant survival rates are higher in patients not receiving radiotherapy after tumor surgery [24,3639]. Dental implant failures are rare in doses less than 45 Gy. In published studies, the risk of implant failure has been reported to be increased due to loss of repair and neovascularization in irradiated bone at radiation doses of $50 \mathrm{~Gy}$ and above [24,38,4043]. There is no consensus on whether HBOT should be used as adjuvant therapy in patients undergoing radiotherapy. Various authors have reported that adjuvant HBOT should be applied to increase the viability of bone and soft tissue, reduce the risk of ORN, and improve osseointegration before implant surgery. Increased oxygen amount, collagen production, and fibroblastic activity increase capillary neoangiogenesis and bone formation $[14,20,44-$ 46].

In studies, it is recommended that HBOT be used to prevent ORN in cases where a dose of more than $50 \mathrm{~Gy}$ and radiation damage shows clinical signs $[7,45,47,48]$. There are also studies reporting that the total radiation doses between 50 and 60 Gy are limit values for rehabilitation with dental implants without the need for additional treatments such as HBOT [22, 49-51]. In a systematic review published by Shah et al in 2017, it has been reported that HBOT reduces the risk of implant failure by increasing vascularization in patients undergoing radiotherapy [20].

Curi et al., reported a success rate of $88.2 \%$ for 5 years in 13 patients undergoing HBOT. In 22 patients without HBOT, this rate was reported as $94.1 \%$. As a result, no significant difference was reported between the two groups [21]. Mancha De La Plata et al., applied HBOT to 4 patients who developed ORN after radiotherapy. They reported that dental implants can be applied after radiotherapy without the need for HBOT [25]. In 2007, Schoen et al., started broad spectrum antibiotic prophylaxis (cefradine $1 \mathrm{~g}$, 3 times a day for 2 weeks) one day before surgery in 13 patients in the control group. 13 patients in the test group received HBOT 20 preoperatively and 10 postoperatively. In addition, antibiotic prophylaxis applied to the test group was applied to the control group. 8 implants failed in 5 patients in the test group, 3 implants failed in 2 patients in the control group. More implant loss was observed in the group with HBOT. As a result, it has been reported that HBOT cannot prevent dental implant failure and complications such as ORN caused by radiotherapy [14]. In published studies, it has been reported that a positive effect of HBOT on implant success was not observed [18, 25, 42,52,53]. In a study conducted 
by $\mathrm{Wu}$ et al. in 2016, it was reported that there was no significant difference in implant success in the group that received HBOT [54]. In systematic reviews published in 2003 and 2008, Coulthard et al. reported that they did not find evidence to support or refute HBOT administration to improve implant survival in patients undergoing radiotherapy $[13,30]$. Another Cochrane review published by Esposito et al., HBOT has not been reported to have a positive effect on the success of implants placed in radiotherapy-treated jaws. In addition, in this review it was reported that more clinical studies are needed on the subject [12].

\section{Conclusion}

When the current limited number of studies are evaluated, it can be seen that HBOT may not provide significant clinical benefit in HNC patients with radiotherapy. In most studies, the time interval between radiotherapy and HBOT is not mentioned. The time between radiotherapy and implant surgery can also affect success. In addition, the studies carried out have limited cohort size and short follow up periods. Therefore, there is a need for randomized, controlled, double-blind trials with homogeneous patient distribution, longer follow-up, supporting HBOT use after RT. Finally, since each center may have a limited number of patients, it is necessary for researchers to consider that these studies may need to be multi-centered.

\section{Acknowledgement}

The authors deny any conflicts of interest related to this study.

\section{Conflict of Interest}

No conflict of interest.

\section{References}

1. Bray F, Ferlay J, Soerjomataram I, Siegel RL, Torre LA, et al. (2018) Global cancer statistics 2018: GLOBOCAN estimates of incidence and mortality worldwide for 36 cancers in 185 countries. CA Cancer J Clin 68(6): 394424.

2. Nayar S (2019) Current concepts and novel techniques in the prosthodontic management of head and neck cancer patients. Br Dent J 226(10): 725-737.

3. Harding S, Courtney D, Hodder S, Bryson P (2012) Effects of hyperbaric oxygen therapy on quality of life in maxillofacial patients with type III osteoradionecrosis. Int J Oral Maxillofac Surg 70 (12): 2786-2792.

4. Sroussi HY, Epstein JB, Bensadoun RJ, Saunders DP, Lalla RV, et al. (2017) Common oral complications of head and neck cancer radiation therapy: mucositis, infections, saliva change, fibrosis, sensory dysfunctions, dental caries, periodontal disease, and osteoradionecrosis. Cancer med 6(12): 2918-2931.

5. Borras JM, Barton M, Grau C, Corral J, Verhoeven R, et al. (2015) The impact of cancer incidence and stage on optimal utilization of radiotherapy: Methodology of a population-based analysis by the ESTRO-HERO project. Radiother and Oncol 116(1): 45-50.

6. Vissink A, Jansma J, Spijkervet F, Burlage F, Coppes R (2003) Oral sequelae of head and neck radiotherapy. Crit Rev Oral Biol Med 14(3): 199-212.

7. Barrowman R, Wilson P, Wiesenfeld D (2011) Oral rehabilitation with dental implants after cancer treatment. Aust Dent J 56(2): 160-165.
8. Beech N, Robinson S, Porceddu S, Batstone M (2014) Dental management of patients irradiated for head and neck cancer. Aust Dent J 59(1): 20-28.

9. Cotic J, Jamsek J, Kuhar M, Hren NI, Kansky A, et al. (2016) Implantprosthetic rehabilitation after radiation treatment in head and neck cancer patients: a case-series report of outcome. Radiol and oncol 51(1): 94-100.

10. Granström G (2003) Radiotherapy, osseointegration and hyperbaric oxygen therapy. Periodontol 33(1): 145-162.

11. Kamstra JI, Jager-Wittenaar H, Dijkstra PU, Huisman PM, Van Oort RP, et al. (2011) Oral symptoms and functional outcome related to oral and oropharyngeal cancer. Support Care Cancer 19(9): 1327-1333.

12. Esposito M, Worthington HV (2013) Interventions for replacing missing teeth: hyperbaric oxygen therapy for irradiated patients who require dental implants. Cochrane Database Syst Rev (9).

13. Coulthard P, Patel S, Grusovin GM, Worthington HV, Esposito M (2008) Hyperbaric oxygen therapy for irradiated patients who require dental implants: a Cochrane review of randomised clinical trials. Eur J Oral Implantol 1(2): 105-10.

14. Schoen PJ, Raghoebar GM, Bouma J, Reintsema H, Vissink A, et al. (2007) Rehabilitation of oral function in head and neck cancer patients after radiotherapy with implant-retained dentures: effects of hyperbaric oxygen therapy. Oral Oncol 43(4): 379-388.

15. Schiegnitz E, Al-Nawas B, Kämmerer P, Grötz K (2014) Oral rehabilitation with dental implants in irradiated patients: a meta-analysis on implant survival. Clin Oral Investig. 18(3): 687-698.

16. Pompa G, Saccucci M, Di Carlo G, Brauner E, Valentini V, et al. (2015) Survival of dental implants in patients with oral cancer treated by surgery and radiotherapy: a retrospective study. BMC Oral Health 15(1): 5

17. Granström G (2006) Placement of dental implants in irradiated bone: the case for using hyperbaric oxygen. Int J Oral Maxillofac Surg 64(5): 812-818.

18. Linsen SS, Martini M, Stark H (2012) Long-term results of endosteal implants following radical oral cancer surgery with and without adjuvant radiation therapy. Clin Implant Dent Relat Res 14(2): 250-258.

19. Pompa G, Brauner E, Jamshir S, De Angelis F, Giardino R, et al. (2017) Quality of life in patients rehabilitated with palatal obturator without reconstruction versus fixed İmplant-prosthesis after reconstruction of maxillectomy defects. J Int Dent Medical Res 10(1).

20. Shah DN, Chauhan CJ, Solanki JS (217) Effectiveness of hyperbaric oxygen therapy in irradiated maxillofacial dental implant patients: A systematic review with meta-analysis. J Indian Prosthodont Soc 17(2): 109-119.

21. Curi M, Condezo A, Ribeiro K, Cardoso C (2018) Long-term success of dental implants in patients with head and neck cancer after radiation therapy. Int J oral max surg 47(6): 783-788.

22. Shaw RJ, Sutton AF, Cawood JI, Howell RA, Lowe D, et al. (2005) Oral rehabilitation after treatment for head and neck malignancy. Head Neck 27(6): 459-470.

23. De Felice F, de Vincentiis M, Valentini V, Musio D, Mezi S, et al. (2017) Management of salivary gland malignant tumor: the Policlinico Umberto I, "Sapienza" University of Rome Head and Neck Unit clinical recommendations. Crit Rev Oncol. Hematol 120: 93-97.

24. Yerit KC, Posch M, Seemann M, Hainich S, Dörtbudak O, et al. (2006) Implant survival in mandibles of irradiated oral cancer patients. Clin Oral Implants Res 17(3): 337-344.

25. de la Plata MM, Gías LN, Díez PM, Muñoz Guerra M, González-García R, et al. (2012) Osseointegrated implant rehabilitation of irradiated oral cancer patients. Int J Oral Maxillofac Surg 70(5): 1052-1063.

26. Brauner E, Quarato A, De Angelis F, Pompa G, Jamshir S, et al. (2017) Prosthetic rehabilitation involving the use of implants following a fibula 
free flap reconstruction in the treatment of Osteosarcoma of the maxilla: a case report. Clin Ter 168(6): e392-e396.

27. Moen I, Stuhr LE (2012) Hyperbaric oxygen therapy and cancer-a review. Target Oncol 7(4): 233-242.

28. Kaur S, Pawar M, Banerjee N, Garg R (2012) Evaluation of the efficacy of hyperbaric oxygen therapy in the management of chronic nonhealing ulcer and role of periwound transcutaneous oximetry as a predictor of wound healing response: a randomized prospective controlled trial. Anaesthesiol Clin Pharmacol 28(1): 70-75

29. Marx RE, Johnson RP, Kline SN (1985) Prevention of osteoradionecrosis: a randomized prospective clinical trial of hyperbaric oxygen versus penicillin. J Am Dent Assoc 111(1): 49.

30. Coulthard P, Esposito M, Worthington HV, Jokstad A (2003) Therapeutic use of hyperbaric oxygen for irradiated dental implant patients: a systematic review. J Dent Educ 67(1): 64-68.

31. Johnsson K, Hansson Å, Granström G, Jacobsson M, Turesson I (1993) The effects of hyperbaric oxygenation on bone-titanium implant interface strength with and without preceding irradiation. Int J Oral Maxillofac Implants 8(4): 415-9.

32. Williamson R (2007) An experimental study of the use of hyperbaric oxygen to reduce the side effects of radiation treatment for malignant disease. Int J Oral Maxillofac Surg 36(6): 533-540.

33. Forner L, Hyldegaard O, von Brockdorff AS, Specht L, Andersen E, et al. (2011) Does hyperbaric oxygen treatment have the potential to increase salivary flow rate and reduce xerostomia in previously irradiated head and neck cancer patients? A pilot study. Oral Oncol47(6): 546-551.

34. Esposito M, Hirsch JM, Lekholm U, Thomsen P (1998) Biological factors contributing to failures of osseointegrated oral implants, (II). Etiopathogenesis. Eur J Oral Sci 106(3): 721-764.

35. Salinas TJ, Desa VP, Katsnelson A, Miloro M (2010) Clinical evaluation of implants in radiated fibula flaps. Int J Oral Maxillofac Surg. 68(3): 524 549.

36. Anderson L, Meraw S, Al-Hezaimi K, Wang HL (2013) The influence of radiation therapy on dental implantology. Implant Dent 22(1): 31-38.

37. Vosselman N, Alberga J, Witjes MH, Raghoebar GM, Reintsema H, et al. (2020) Prosthodontic rehabilitation of head and neck cancer patientschallenges and new developments. Oral Dis.

38. Granström G (2005) Osseointegration in irradiated cancer patients: an analysis with respect to implant failures. Int J Oral Maxillofac Surg 63(5): 579-585

39. Korfage A, Schoen PJ, Raghoebar GM, Roodenburg JL, Vissink A (2010) Benefits of dental implants installed during ablative tumour surgery in oral cancer patients: a prospective 5-year clinical trial. Clin Oral Implants Res 21(9): 971-979.

40. Colella G, Cannavale R, Pentenero M, Gandolfo S (2007) Oral implants in radiated patients: a systematic review. Int J Oral Maxillofac Implants 22(4): 616-622.
41. Ihde S, Kopp S, Gundlach K, Konstantinović V (2009) Effects of radiation therapy on craniofacial and dental implants: a review of the literature. Oral Surg Oral Med Oral Pathol Oral Radiol Endod 107(1): 56-65.

42. Schoen PJ, Reintsema H, Raghoebar GM, Vissink A, Roodenburg JL (2004) The use of implant retained mandibular prostheses in the oral rehabilitation of head and neck cancer patients. A review and rationale for treatment planning. Oral Oncol 40(9): 862-871.

43. Tanaka TI, Chan HL, Tindle DI, MacEachern M, Oh TJ (2013) Updated clinical considerations for dental implant therapy in irradiated head and neck cancer patients. J Prosthodont 22(6): 432-438.

44. Niimi A, Fujimoto T, Nosaka Y, Ueda M (1997) A Japanese multicenter study of osseointegrated implants placed in irradiated tissues: a preliminary report. Int J Oral Maxillofac Implants 12(2): 259-264.

45. Larsen PE (1997) Placement of dental implants in the irradiated mandible: a protocol involving adjunctive hyperbaric oxygen. Int J Oral Maxillofac Surg 55(9): 967-971.

46. Chambrone L, Mandia J, Shibli J, Romito G, Abrahao M (2013) Dental implants installed in irradiated jaws: a systematic review. J Dent Res 92(12_suppl): 119S-30S.

47. Keller E (1997) Placement of dental implants in the irradiated mandible: a protocol without adjunctive hyperbaric oxygen. J Oral Maxillofac Surg 55(9): 972-980.

48. Nabil S, Samman N (2012) Risk factors for osteoradionecrosis after head and neck radiation: a systematic review. Oral Surg Oral Med Oral Pathol Oral Radiol 113(1): 54-69.

49. Dholam KP, Pusalkar HA, Yadav PS, Quazi GA, Somani PP (2013) Implantretained dental rehabilitation in head and neck cancer patients: an assessment of success and failure. Implant Dent 22(6): 604-609.

50. Visch L, Van Waas M, Schmitz P, Levendag P (2002) A clinical evaluation of implants in irradiated oral cancer patients. J. Dent Res 81(12): 856869.

51. Sammartino G, Marenzi G, Cioffi I, Teté S, Mortellaro C (2011) Implant therapy in irradiated patients. J Craniofac Surg 22(2): 443-445.

52. Chrcanovic BR, Albrektsson T, Wennerberg A (2016) Dental implants in irradiated versus nonirradiated patients: A meta-analysis. Head Neck 38(3): 448-481.

53. Schepers R, Slagter A, Kaanders J, Van den Hoogen F, Merkx M (2006) Effect of postoperative radiotherapy on the functional result of implants placed during ablative surgery for oral cancer. Int J Oral Maxillofac Surg 35(9): 803-808.

54. Wu Y, Huang W, Zhang Z, Zou D (2016) Long-term success of dental implant-supported dentures in postirradiated patients treated for neoplasms of the maxillofacial skeleton: a retrospective study. Clin Oral Investig 20(9): 2457-2465 